\title{
Penerapan Fitur Warna Untuk Identifikasi Plasmodium Falciparum pada Sediaan Apus Darah Menggunakan MK-Means dan Jaringan Backpropagation
}

\author{
Mustamin Hamid, Panca Mudjirahardjo, Erni Yudaningtyas
}

\begin{abstract}
This research proposed a system to identify Plasmodium falciparum on blood smear using the neural network backpropagation. Modified K-Means (MKMeans) is used to separate between the object with the background image because that method was able to equalize the value of fitness at all Center cluster so there is no dead center and can also cope with the local minimum value. The extraction of the features used in this study consists of color features i.e. calculation of the mean, standard deviation, skewness, curtosis and entropy of cooccurent matrix with the purpose to get the values of all the trait value image, obtained are then used to train a neural network with the backpropagation training algorithm. Method of backpropagation networks capable of acquiring knowledge even though there is no certainty, able to perform a generalization and extraction of a specific data pattern.

The image of the preparations blood smear are classified using the method of neural network Backpropagation. The test results obtained from Tropozoit with the accuracy $100 \%$, scizon $80 \%$ and gametocytes $80 \%$. Identification is then obtained outcomes the introduction with an average accuracy of $86,66 \%$.
\end{abstract}

Keywords: MK-Means, Plasmodium falciparum, Backpropagation Network.

Abstrak - Penelitian ini mengajukan sebuah sistem untuk mengidentifikasi Plasmodium falciparum pada sediaan apus darah menggunakan jaringan syaraf tiruan backpropagation. Algoritma yang digunakan terdiri dari empat langkah, pengolahan awal, segmentasi citra, ekstraksi fitur dan klasifikasi. Segmentasi citra smear

Manuscript received October 18, 2016. (Write the date on which you submitted your paper for review.) This work was supported in part by Electrical Engineering Department University of Brawijaya Mustamin Hamid is with the Electrical Engineering Departement, Faculty of Engineering, Brawijaya University, Malang, Indonesia (email:hamidmustamin@gmail.com)

Panca Mudjirahardjo was the Electrical Engineering Departement, Faculty of Engineering,Brawijaya University, Malang, Indonesia (panca@ub.ac.id)

Erni Yudaningtyas is Electrical Engineering Departement, Faculty of Engineering,Brawijaya University, Malang, Indonesia (erni@ub.ac.id) darah menggunakan metode Modified K-Means (MKMeans). Ekstraksi fitur yang digunakan dalam penelitian ini terdiri dari fitur warna yakni perhitungan mean, standar deviasi, skewness, curtosis dan entropy dari cooccurent matrik, nilai ciri digunakan untuk melatih jaringan neural dengan algoritma pelatihan backpropagation. citra sediaan apus darah diklasifikasi menggunakan metode jaringan syaraf tiruan Backpropagation. Menggunakan algoritma tersebut, diperoleh hasil pengenalan dengan akurasi $86,66 \%$.

Kata kunci : MK-Means, Plasmodium falciparum, Jaringan Backpropagation.

\section{PENDAHULUAN}

$\mathrm{M}$ alaria merupakan salah satu penyakit menular yang masih menjadi masalah kesehatan masyarakat di dunia termasuk Indonesia. Penyakit ini mempengaruhi tingginya angka kematian bayi, balita dan ibu hamil [1]. Annual Parasite Incidence (API) per 1000 penduduk mengatakan bahwa Papua memiliki presentasi kasus terbesar yakni $42,65 \%$, sementara Papua Barat sebesar 38,44\%, NTT sebesar 16,37\%, Maluku sebesar $8,25 \%$, dan Maluku Utara sebesar 4,51\%. [2].

Malaria disebabkan oleh parasit darah perifer dari genus Plasmodium. Genus Plasmodium memiliki lima spesies yang dapat menyebabkan infeksi pada manusia yaitu plasmodium malariae, plasmodium vivax, plasmodium ovale, dan. plasmodium falciparum [3], Plasmodium falciparum merupakan salah satu jenis penyakit malaria yang paling berbahaya dibandingkan ketiga spesies lainnya, oleh karena potensinya yang dapat menyebabkan infeksi paling berbahaya dan memiliki tingkat komplikasi dan mortalitas malaria tertinggi [4].

Saat ini teknik diagnosis berdasarkan pada pemeriksaan mikroskopis slide darah masih tetap menjadi standar utama untuk diagnosis laboratorium malaria[5]. Namun ketelitian dan konsentrasi dalam mengenali parasit malaria tergantung pada subyektifitas pengalaman hematologis [6]. Dengan adanya perkembangan pada bidang pengolahan citra medis dan sistem diagnosis yang terbantu komputer, 
diharapkan dapat mengurangi efek subyekfitas dan membantu dokter dalam proses diagnosis.

Penelitian terkait telah diteliti oleh Purnama E, dkk.[7] mengidentifikasi citra sediaan darah parasit malaria berdasarkan RGB chanel histogram, HSI histogram dan HSV histogram diperoleh menggunakan perhitungan mean, standar deviasi, skewness, kurtosis dan entropy. Nasir A, dkk [8] telah melakukan segmentasi untuk mendeteksi parasit malaria pada sediaan darah tipis menggunakan median filter, kemudian melakukan segmentasi moving $K$-means untuk menghilangkan objek yang tidak terpakai pada citra sediaan darah. Memeu,M.D., dkk.,[9] meneliti tentang deteksi malaria menggunakan metode Artificial Neural Network (ANN) untuk menguji adanya parasit plasmodium dalam gambar sediaan apus darah. Keunggulan ANN adalah mampu mengakuisisi pengetahuan walau tidak ada kepastian, mampu melakukan generalisasi dan ekstraksi dari suatu pola data tertentu, dapat menciptakan suatu pola pengetahuan melalui pengaturan diri kemampuan belajar (self organizing), dan mampu menghitung secara parallel sehingga proses lebih singkat.

Pada penelitian ini bertujuan membuat suatu alat bantu untuk mengidentifikasi adanya sel parasit plasmodium falciparum pada citra sediaan apus darah berdasarkan morfologi sel darah merah (eritrosit) yang terbantukan komputer menggunakan konsep pengolahan citra digital, dan artificial intelligent guna standarisasi persepsi keilmuan dan untuk mempercepat waktu analisis. MK-Means mampu menyamakan nilai pada fitness dari semua pusat cluster sehingga tidak ada pusat mati (dead centre) yang sering terjadi pada K-Means biasa, pusat cluster akan lebih banyak dialokasikan pada area populasi data yang besar dan metode ini dapat mengatasi nilai local minimum. Pada penelitian ini, MK-Means akan digunakan untuk memisahkan latar belakang dengan sel eritrosit berdasarkan kernel. Analisis pengekstrakan ciri diperlukan untuk memberikan prognosis yang digunakan dalam penelitian ini seperti mean, standar deviasi, kurtosis, skewness, dan entropy. Berdasarkan analisis pengekstrakan ciri, jaringan backpropagation digunakan untuk proses klasifikasi sel parasit plasmodium falciparum didalam sel eritrosit.

\section{DATA}

Data berupa citra sediaan darah parasit malaria yang digunakan dalam penelitian ini diperoleh public health image library (PHIL) dari phil.cdc.gov. objek penelitian berupa citra preparat darah terinfeksi parasit malaria yaitu citra falciparum thropozoit, falciparum schizont, dan falciparum gametosit dengan format JPG. Proses normalisasi seperti cropping dan resize untuk menyamakan dimensi citra dilakukan secara manual sehingga menjadi citra tunggal dengan ukuran $130 \mathrm{x}$ 130 piksel seperti terlihat pada Gambar 1.

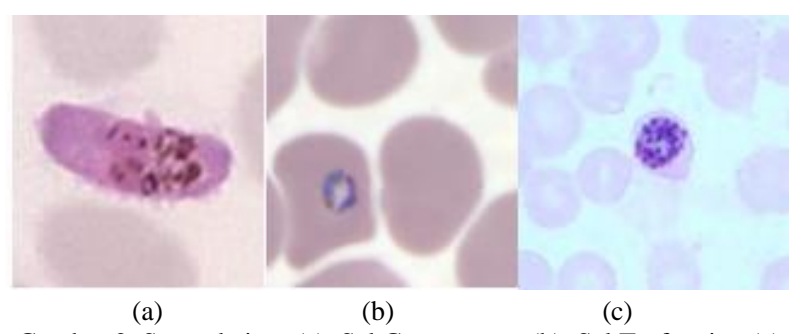

Gambar 2. Sampel citra, (a). Sel Gametocyte, (b). Sel Trofozoite, (c). Sel Scizon (Sumber : phil.cdc.gov)

III. METODE PENELITIAN

Metode yang diusulkan dalam penelitian ini dapat dilihat pada Gambar 2. Metodologi yang digunakan meliputi pengolahan awal citra, segmentasi citra, ekstraksi fitur dan klasifikasi.

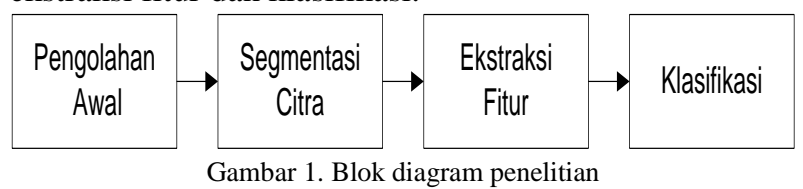

\section{A. Pengolahan Awal}

Pengolahan awal bertujuan untuk memperbaiki kualitas citra. Pada penelitian ini digunakan metode median filter. Median filter dapat digunakan untuk mengurangi noise pada suatu citra dalam domain spasial [10]. Median filter merupakan salah satu metode yang menggunakan mask processing. Pada median filter untuk menentukan nilai masknya berdasarkan pengurutan nilai piksel di sekitar mask yang telah ditentukan, dan dicari nilai tengahnya. Contoh piksel citra dengan mask 3x3 ditunjukkan pada Gbr. 3 .

Berikut cara mencari nilai tengah dari mask yang telah ditentukan:

- Mengurutkan nilai piksel dari mask yang telah ditentukan.

9,10,10,10,10,10,11,12,35

- Penentuan nilai tengah yaitu 10

- Nilai 10 menggantikan nilai 35 yang terdapat pada tengah mask.

\begin{tabular}{|l|l|l|l|l|}
\hline 13 & 10 & 15 & 14 & 18 \\
\hline 12 & 10 & 10 & 10 & 15 \\
\hline 11 & 11 & 35 & 10 & 10 \\
\hline 13 & 9 & 12 & 10 & 12 \\
\hline 13 & 12 & 9 & 8 & 10 \\
\hline
\end{tabular}

Gbr. 3 Contoh piksel citra dengan mask $3 \times 3$ (Sumber : jannah, 2008)

\section{B. Segmentasi Citra}

Segmentasi citra bertujuan untuk memisahkan antara objek yang satu dengan objek yang lain dalam suatu citra. Pada penelitian ini menggunakan teknik segmentasi MK-Means berdasarkan warna. citra sediaan apus darah plasmodium falciparum dibagi menjadi tiga bagian yakni Red Blood Cel (RBC) atau sel darah merah, parasit inti berwarna biru tua, dan latar belakang berwarna putih. MK-Means dapat memisahkan komponen-komponen tersebut berdasarkan warna. Jumlah kelas didefinisikan terlebih dahulu dan berdasarkan jarak Euclidian kemudian masing-masing komponen dikelompok-kan [11]. Setelah citra 
tersegmentasi kemudian dilakukan proses operasi morfologi untuk memperbaiki kualitas citra berdasarkan operasi matematika yang terdiri dari erosi dan dilasi. Operasi erosi dilakukan untuk penghapusan titik-titik objek, sedangkan operasi dilasi dilakukan untuk memperbesar ukuran segmen objek dengan menambah lapisan di sekeliling objek.

\section{Ekstraksi Fitur Warna}

Ekstraksi fitur merupakan suatu pengambilan ciri / fitur dari suatu citra yang nantinya nilai yang didapatkan akan dianalisis untuk proses selanjutnya. Pada penelitian ini digunakan ekstraksi fitur warna, ada beberapa parameter yang akan diekstrak berdasarkan ciri warna yaitu :

- Nilai piksel rata-rata (Mean)

Nilai piksel rata-rata atau mean merupakan suatu nilai yang menunjukan ukuran distribusi dari suatu citra. Dan dihitung menggunakan rumus :

$$
\text { Mean }=\mu=\frac{1}{n} \sum_{i=1}^{n} x i
$$

- Standar Deviasi

Standar deviasi atau varians adalah ukuran data yang tersebar pada suatu data. Rumusnya sebagai berikut :

$$
S d=s=\left(\frac{1}{n} \sum_{i=1}^{n}(x i-\mu)^{2}\right)^{\frac{1}{2}}
$$

- $\quad$ Skewness dan Curtosis

Skewness (kecondongan) dan curtosis (keruncingan) merupakan rata-rata nilai piksel (Px) dikurangi mean $(\mu)$ kemudian dipangkatkan dengan $\mathrm{n}$ pada masing-masing channel RGB. Distribusi dikatakan condong kekiri, apabila nilai skewness memiliki nilai skewness berupa bilangan negative. Sebaliknya, distribusi dikatakan condong ke kanan apabila memiliki nilai skewness berupa bilangan positif.

$$
\begin{aligned}
& \text { Skewness }=\frac{\frac{1}{n} \sum_{i=1}^{n}(x i-\mu)^{3}}{\left(\sqrt{\frac{1}{n} \sum_{i=1}^{n}(x i-\mu)^{2}}\right)^{3}} \\
& \text { Kurtosis }=k=\frac{\frac{1}{n} \sum_{i=1}^{n}(x i-\mu)^{4}}{\left(\frac{1}{n} \sum_{i=1}^{n}(x i-\mu)^{2}\right)^{2}}
\end{aligned}
$$

- Entropy

Entropy adalah nilai keteracakan distribusi warna yang diperoleh dari matriks co-occurence dengan persamaan sebagai berikut :

$$
\begin{aligned}
& E=-\sum_{i 1} \sum_{i 2} p(i 1, i 2) \log p(i 1, i 2) \\
& \text { D. Klasifikasi }
\end{aligned}
$$

Pada tahap ini dilakukan pengenalan yang terdiri dari pembelajaran dan pengujian pada sel plasmodium falciparum menggunakan jaringan backpropagation. Jaringan backpropagation merupakan algoritma klasifikasi yang meniru prinsip kerja jaringan syaraf manusia. Algoritma ini memetakan data masukan pada layer masukan menuju layer keluaran melalui neuronneuron pada layer tersembunyi. Hasil yang diperoleh kemudian dibandingkan dengan data target sehingga diperoleh tingkat kesalahan (error rate), apabila tingkat kesalahan yang diperoleh lebih kecil maka proses akan berhenti, namun apabila tingkat kesalahan lebih besar maka dilakukan proses perambatan balik dengan pembaharuan bobot. Pada penelitian ini pelatihan ditujukan untuk mengenal pola-pola citra.

- Pelatihan

Langkah-langkah pelatihan jaringan perambatan balik adalah sebagai berikut :
0. Instalasi bobot.

(bobot diberi nilai acak yang kecil)

1. Jika kondisi berhenti salah, kerjakan 2-9.

2. Untuk tiap pasangan pola masukan,kerjakan 3-8. Umpan-maju :

3. Tiap unit masukan $(\mathrm{Xi}, \mathrm{I}=1, \ldots, \mathrm{n})$ menerima sinyal masukan xi dan meneruskan sinyal ini ke semua unit pada lapisan di atasnya (unit tersembunyi).

4. Tiap unit tersembunyi $(\mathrm{Zj}, \mathrm{j}=1, \ldots, \mathrm{p})$ hitung sinyal masukan bobotnya,

$z_{i n_{j}}=v_{0 j}+\sum_{i=1}^{n} x_{i} v_{i j}$

Terapkan fungsi aktivasinya untuk menghitung sinyal keluaran,

$z_{j}=f\left(z_{-} i n_{j}\right)$

Dan kirim sinyal ini ke semua unit pada layer diatasnya (unit keluaran).

5. Tiap unit keluaran $(\mathrm{Yk}, \mathrm{k}=1, \ldots, \mathrm{m})$ hitung sinyal masukan bobotnya,

$y_{-} i n_{k}=w_{0 k}+\sum_{j=1}^{p} z_{j} w_{j k}$

Dan terapkan fungsi aktivasinya untuk menghitung sinyal keluaran,

$y_{k}=f\left(y_{-} i n_{k}\right)$

Perambatan balik galat :

6. Tiap unit keluaran $(\mathrm{Yk}, \mathrm{k}=1, \ldots, \mathrm{m})$ menerima pola target yang bersesuaian dengan pola masukan, dihitung parameter informasi galat,

$\delta_{k}=\left(t_{k}-y_{k}\right) f\left(y_{-} i n_{k}\right)$

Hitung parameter koreksi bobotnya (dipakai untuk mengubah wjk),

$\Delta w_{j k}=a \delta_{k} z_{j}, a=$ pusat pembelajaran

Hitung parameter koreksi bias (dipakai untuk mengubah w0k)

$$
\Delta w_{0 k}=a \delta_{k}
$$

Dan kirim $\delta_{k}$ ke unit-unit dibawahnya.

7. Tiap unti tersembunyi $(\mathrm{Zj}, \mathrm{j}=1, \ldots, \mathrm{p})$ hitung masukan deltanya (dari unit pada lapisan dibawahnya),

$\delta_{-} i n_{j}=\sum_{k=1}^{m} \delta_{k} w_{j k}$

Kalikan dengan turunan fungsi aktivasinya untuk menghitung parameter informasi galatnya,

$\delta_{j}=\delta_{-} i n_{j} f^{\prime}\left(z_{-} i n_{j}\right)$

Hitug parameter koreksi bobotnya (dipakai untuk mengubah vij),

$\Delta v_{i j}=a \delta_{j} x_{i}$

Hitung parameter koreksi bias (dipakai untuk mengubah v0j),

$\Delta v_{0 j}=a \delta_{j}$

Perbaharui bobot dan bias:

8. Tiap unit keluaran $(\mathrm{Yk}, \mathrm{k}=1, \ldots, \mathrm{m})$ ubah bias dan bobotnya $(\mathrm{j}=0, \ldots, \mathrm{p})$ :

$w_{j k}($ baru $)=w_{j k}(\operatorname{lama})+\Delta w_{j k}$

Tiap unit tersembunyi $(\mathrm{Zj}, \mathrm{j}=1, \ldots, \mathrm{p})$ ubah bias dan bobotnya $(\mathrm{I}=0, \ldots, \mathrm{n})$ :

$v_{i j}($ baru $)=v_{i j}($ lama $)+\Delta v_{i j}$ 


\section{UJI COBA DAN EVALUASI}

Peralatan bantu yang digunakan pada penelitian ini adalah :

- Computer dengan spesifikasi : processor Intel(R) Celeron(R) 1.50GHz, RAM 2.00GB, Harddisk 500GB

- Program bantu MATLAB R2013a beserta toolbox neural network untuk pemrosesan sampel darah plasmodium falciparum dan pelatihan serta pengujian jaringan neural perambatan balik

A. Pengolahan Awal Citra

Perbaikan kualitas citra pada proses ini dilakukan per-kanal warna untuk menghilangkan noise pada citra aquisisi menggunakan median filter dengan ukuran mask $3 \times 3$. Hasil citra akan ditampilkan pada Gambar 4.

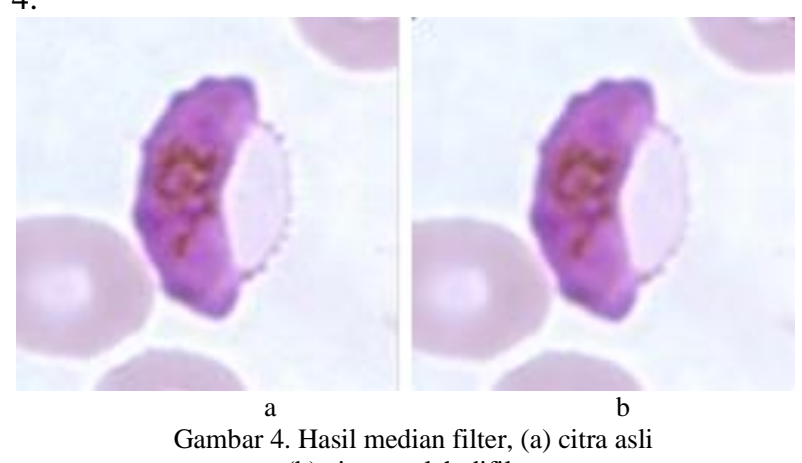

(b) citra setelah difilter

Pada gambar 4. Citra sebelum difilter terlihat adanya noise berupa speckle atau bercak putih, setelah difilter hasilnya menjadi lebih baik. Untuk pengukuran hasil kualitas citra agar lebih obyektif dapat dihitung menggunakan pengukuran statistik seperti MSE (mean square error) dan PSNR (peak signal to noise ratio).

$M S E=\frac{1}{M N} \sum_{x=1}^{M} \sum_{y=1}^{N}\left[f(x, y)-f^{\prime}(x, y)\right]^{2}$

$P S N R=20 * \log ^{10} \frac{255}{\sqrt{M S E}}$

Dimana : $f(x, y)$ adalah nilai piksel dari citra asli

$f^{\prime}(x, y)$ adalah nilai piksel pada citra hasil kompresi

$M, N$ adalah dimensi image

Berdasarkan hasil perhitungan menggunakan pengukuran statistic MSE dan PSNR yang telah ditentukan yaitu nilai MSE yang baik adalah mendekati 0 dan nilai PSNR >30 dB [12] sehingga pada hasil median filter diatas nilai MSE rendah yaitu 5,3080 dan nilai PSNR tinggi yaitu 40,8815. Dari hasil tersebut mengindikasikan citra hasil rekonstruksi memiliki kualitas yang bagus.

B. Segmentasi Citra

Pada tahap ini, citra RGB dikonversi ke ruang warna HSI. Dipilih format ini karena ruang warna HSI (hue, saturation, intensity) merupakan ruang warna yang komponen-komponennya berkontribusi langsung pada persepsi visual manusia sehingga lebih mempermudah pada saat proses segmentasi. Berdasarkan warna-warna dominan yang terdapat pada citra sediaan apus darah plasmodium falciparum, MK-Means dapat mengelompokkan citra kedalam tiga bentuk warna yaitu latar belakang (putih), $R B C$ (merah) dan inti sel parasit malaria (biru). Gambar 5. adalah citra plasmodium falciparum hasil MK-Means.
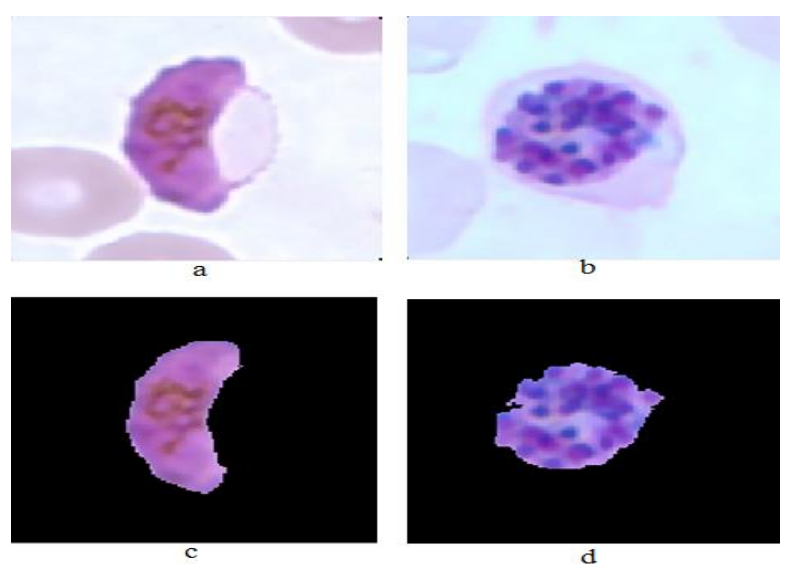

Gambar 5(a),(b) Citra asli, (c),(d) citra hasil segmentasi modified k-means.

\section{Ekstraksi Fitur Warna}

Berdasarkan fitur yang telah dipaparkan diatas, citra sediaan apus darah plasmodium falciparum setelah segmentasi diekstrak untuk mendapatkan nilai-nilai fiturnya berdasarkan perhingan mean, standar deviasi, skewness, curtosis dan entropy agar mempermudah dalam proses klasifikasi. Citra hasil ekstraksi fitur warna dapat dilihat pada Tabel 1 .

Tabel 1.Ekstraksi fitur pada Gambar 5

\begin{tabular}{|l|r|r|r|r|r|}
\hline & mean & $\begin{array}{l}\text { Standar } \\
\text { deviasi }\end{array}$ & kkewness & curtosis & entropy \\
\hline RGB_R(a) & 50.5889 & 82.1359 & 1.04286 & -0.846255 & 2.56034 \\
\hline RGB_G(a) & 34.1543 & 56.405 & 1.13945 & -0.520841 & 2.6468 \\
\hline RGB_B(a) & 45.6254 & 74.7328 & 1.08859 & -0.708632 & 2.63056 \\
\hline RGB_R(b) & 30.9238 & 62.5402 & 1.64334 & 0.945498 & 2.14716 \\
\hline RGB_G(b) & 23.2021 & 47.5932 & 1.73638 & 1.3831 & 2.1268 \\
\hline RGB_B(b) & 46.5396 & 91.7552 & 1.47905 & 0.223364 & 1.94138 \\
\hline
\end{tabular}

Dari Tabel 1 maka dibentuklah vektor masukan jaringan Backpropagation, yaitu jumlah warna (RGB) dikalikan dengan jumlah fitur warna $(3 \times 5)$ sehingga menghasilkan 15 vektor masukan untuk proses pengujian.

\section{Klasifikasi}

Klasifikasi yang digunakan dalam penelitian ini adalah jaringan backpropagation. Hasil beberapa percobaan untuk menentukan jumlah neuron tersembunyi, diperoleh arsitektur jaringan yang digunakan adalah 15 vektor masukan, 5 neuron tersembunyi dan 3 klasifikasi keluaran dan disertai dengan parameter-parameter yang sudah dijelaskan diatas, maka akan diperoleh hasil seperti pada plot performance dan plot regression untuk 15 citra pengujian. Proses tersebut ditunjukan pada Gambar 7.

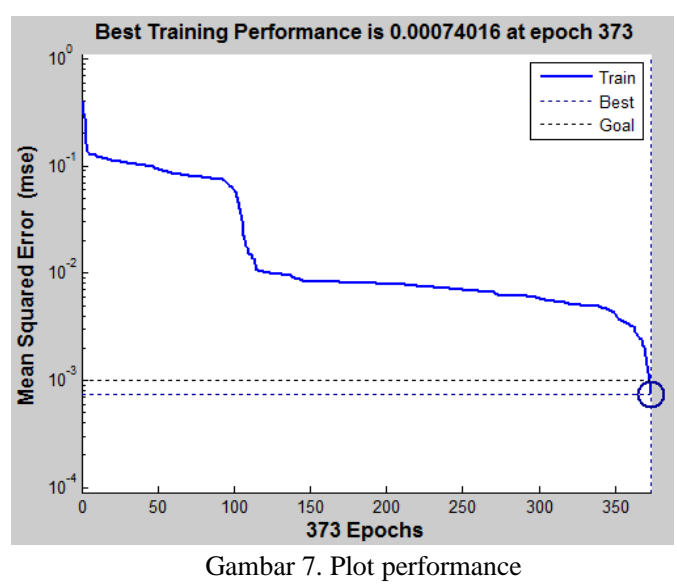




\section{$>$ Plot Performance}

Jika garis train menurun sampai pada goal (jumlah error minimum yang diinginkan), maka dinyatakan berhasil. Grafik tersebut menyatakan Goal tercapai pada Epoch (iterasi) ke-373.

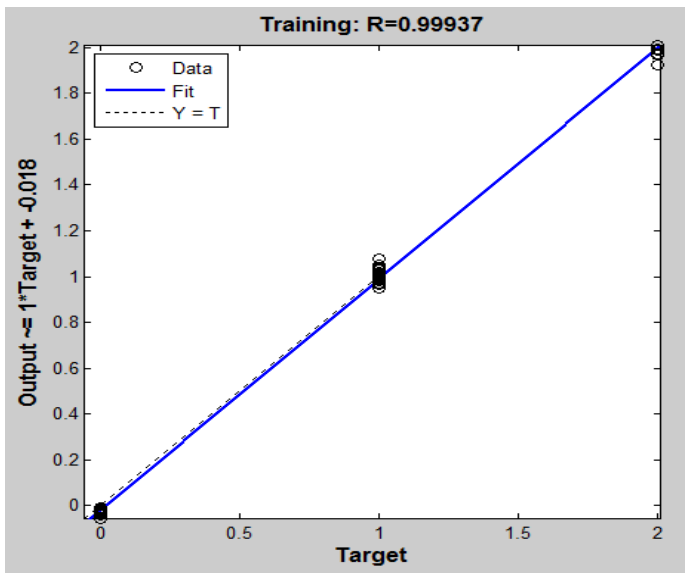

Gambar 8. Plot regression

\section{$>$ Plot Regression}

Dari grafik tersebut diketahui, gradient garis hasil regresi linear bernilai 1, titik perpotongan dengan sumbu Y bernilai 0.018 (mendekati 0) dan koefisien korelasi bernilai 0.99937 (mendekati 1), menunjukkan hasil yang baik untuk kecocokan output jaringan dengan target.

Pada bagian ini akan dibahas hasil penerapan Jaringan backpropagation terhadapap pengenalan citra sediaan apus darah plasmodium falciparum. Jumlah data pelatihan adalah 67 citra, yang meliputi 30 citra ringtropozoit, 30 citra gametosit dan 7 citra szicon. Sedangkan untuk pengujian sebanyak 15 citra, yang terdiri atas 5 citra ring-tropozoit, 5 citra gametosit dan 5 citra scizon.

Tabel 2.

Hasil pengujian identifikasi plasmodium falciparum

\begin{tabular}{|l|c|c|c|}
\hline \multirow{2}{*}{} & \multicolumn{3}{|c|}{ HASIL IDENTIFIKASI } \\
\hline & RING & GAMETOSIT & SCIZON \\
\hline RING & $100 \%$ & $0 \%$ & $0 \%$ \\
\hline GAMETOSIT & $0 \%$ & $80 \%$ & $20 \%$ \\
\hline SCIZON & $0 \%$ & $20 \%$ & $80 \%$ \\
\hline
\end{tabular}

Rata-rata identifikasi $=\frac{100+80+80}{3}=86,66 \%$

Hasil pengujian akurasi kinerja JST backpropagation seperti ditunjukkan pada Tabel 2. Menunjukkan hasil untuk tiga fase citra sediaan apus darah plasmodium falciparum yang terdiri dari ringtropozoit, Gametosit dan Scizon. Hasil pengujian menunjukan bahwa system dapat mendeteksi semua kelas dengan sangat baik, dimana ring-tropozoit dengan akurasi mencapai $100 \%$, gametosit $80 \%$ dan scizon $80 \%$. Akurasi rata-rata dari system yang diusulkan adalah $86,66 \%$.

\section{KESIMPULAN DAN SARAN}

Penelitian ini menjelaskan sistem identifikasi plasmodium falciparum pada sediaan apus darah dengan menggunakan ekstraksi fitur warna. Pengaplikasian median filter, MK-Means dan operasi morfologi dilakukan agar dapat menghindari keadaan oversegmentation. Metode klasifikasi digunakan neural network backpropagation.

Dari hasil penelitian menunjukan penerapan fitur warna dapat digunakan untuk seleksi ciri dengan sampel yang cukup, dan penggunaan jaringan backpropagation baik untuk pengenalan ini.

Penelitian mendatang untuk memperbaiki system ini adalah dengan menambah fitur bentuk dan fitur tekstur lain.

\section{REFERENSI}

[1] World Health Organization (WHO). 2011. Universal Access To Malaria Diagnostic Testing An Operational Manual. Switzerland: WHO

[2] Kemenkes RI. 2011. Pedoman Teknis Pemeriksaan Parasit Malaria 2011. Jakarta : Direktorat Jenderal PP dan PL Kementrian Kesehatan RI

[3] Singh, J.C., Davis, T., Lee,K.S.., Shamsul, S, S. G.., Matusop, A.2008. Plasmodium knowlesi malaria in humans is widely distributed and potentially life threatening. Clinical Infectious Disease, Vol.46.

[4] Arsin Arsunan Andi. 2012. Malaria di Indonesia Tinjauan Aspek Epidemologi. Makassar : Masagena Press

[5] Joel, C., Mouatcho., Golding,D. 2013. Malaria Rapid Diagnostic Tests: Challenges And Prospects. South Afrika : Journal of Medical Microbiology.

[6] Reta,C., Altamirano,L., A, Jesus., Gonzales., Diaz,R. Guichard,S.J. 2010. Segmentation of Bone Marrow Cell Images for Morphological Classification of Acute Leukemia. Proceedings of the $23^{\text {rd }}$ International Florida Artificial Intelligence Research Society Conference, USA

[7] Purnama E.K.I., Rahmanti,F.Z., Purnom,M.H. 2013. Malaria Parasite Identification on Thick Blood Film Using Genetic Programming. International Conference on Instrumentation, Communications, Information Technology, and Biomedical Engineering (ICICI-BME). Bandung.

[8] Nasir,A,S.A., Mashor,Y.M., Mohamed,Z. 2012. Segmentation Based Approach for Detection of Malaria Parasites Using Moving K-Means Clustering. IEEE EMBS International Conference on Biomedical Engineering and Sciences. Malaysia.

[9] Memeu,M.D., Kaduki,A.K., Mjomba, A,C.K., Muriuki,S.N. 2013. Detection of plasmodium parasites from images of thin blood smears. Open Journal of Clinical Diagnostics. Kenya.

[10] Sholihin,AR.2016. Perbaikan citra dengan menggunakan median filter dan metode histogram equalization. Issn 14118890. Vol.14.

[11] Mashor,M,Y. 2000. Hybrid training algorithm for RBF network.International Journal of the Computer, the Internet and Management, vol. 8.

[12] Munandar,TB. 2011. Analisis PSNR, rasio kompresi warna dan MSE terhadap kompresi image menggunakan 31 fungsi wavelet. Digital information and system conference 